ISSN:2656-4270 (Online) 1410-4466 (Print) Accredited by Ministry of Research, Technology, and Higher Education with the ranking of Sinta (S4) SK NO.28/E/KPT/2019, 26th September 2019
Buletin Penelitian Sosial Ekonomi Pertanian Fakultas Pertanian Universitas Haluoleo

2020:22(1):12-19

http://ojs.uho.ac.id/index.php/sosek

doi: http://dx.doi.org/10.37149/sosek.v22i1.12318

\title{
THE ANALYSIS OF LEADING PLANT SECTOR COMMODITIES IN NORTH KONAWE DISTRICT
}

\author{
Anas Nikoyan ${ }^{1^{*}}$ \\ ${ }^{1}$ Department of Agricultural Extension Faculty of Agriculture Halu Oleo University, \\ Kendari Indonesia 93232 \\ *Corresponding author: anas.nikoyan_faperta@uho.ac.id \\ To cite this article: \\ Nikoyan, A. (2020). The Analysis of Leading Plant Sector Commodities in North Konawe District. Buletin \\ Penelitian Sosial Ekonomi Pertanian Fakultas Pertanian Universitas Haluoleo, 22(1), 12 - 19. \\ doi:http://dx.doi.org/10.37149/bpsosek.v22i1.12318
}

Received: June 07, 2020; Accepted: July 21, 2020; Published: July 30, 2020

\begin{abstract}
The study aimed to determine the leading commodity in the plantation sector in North Konawe District. The study was conducted in North Konawe District in December 2019. The selection of the research object was carried out purposively with the consideration that North Konawe District is one of the regions in Southeast Sulawesi Province which makes the plantation sector as one of the sectors that have potential and plays an important role in improving regional economy. The study was conducted using a literature review method based on secondary data, namely data obtained from various sources such as the Central Statistics Agency, the Plantation Office, and relevant research results. The analysis of the data used was Location Quotient Analysis (LQ), Dynamic Location Quotient Analysis (DLQ), and Analysis of the Combination of LQ and DLQ. The results showed that the plantation sector commodities in North Konawe District were classified as superior, while those which not yet potential to be superior were coconut, oil palm, coffee, pepper, cashew, sago, candlenut, and nutmeg.
\end{abstract}

Keywords: commodity; dynamic location quotient; location quotient

\section{INTRODUCTION}

The plantation sector is a sector that is able to contribute the improvement of economy and encourage the national development. This is evidenced by statistical data that showed that Indonesia is a country that has the largest plantation area in the world. Around 11.2 million hectares or $80 \%$ are smallholder plantations, while the rest are private owned plantations (PBS) and large state plantations (PBN) (Wulandari \& Kemala, 2016). This means that the plantation sector plays an important role in national development. Its role is evident in the foreign exchange revenues through exports, providing employment, meeting the consumption needs and raw materials of various domestic industries, gaining added value and competitiveness and optimizing sustainable management of natural resources (Hidayat, 2013). These conditions indicate that the plantation sector is a sector that has potential and opportunities to be developed not only at the national level but also at the regional level.

North Konawe District is one of the regions in Southeast Sulawesi Province that makes the plantation sector a driving force for the economy. The North Konawe District Mid-Term Development Plan (RPJMD) for 2016-2021 stated that one of the strategic sectors that sustain community life and regional development and is also the main economic base of the community in North Konawe District for the past few decades is the plantation sector. Seeing these conditions, the sustainable development of the plantation sector will have a positive impact on the development of the North Konawe District. This can be seen from the large contribution of North Konawe District's plantation commodities to the total production of Southeast Sulawesi plantations which showed a fairly high amount of $6.30 \%$ compared to some other sectors of commodities such as food crops amounting to $4.32 \%$ of the total production of Southeast Sulawesi, vegetables at $1.52 \%$ and livestock at $1.09 \%$ (BPS, 2019b). 
Steps towards efficiency in the plantation sector in North Konawe District can be taken by using a superior commodity that has a strategic position, based on technical, socio-economic and institutional considerations (Rachman, 2003). Leading commodity is a potential commodity that is deemed to be competitive with similar products in other regions, because besides having comparative advantages, it also has high business efficiency. In addition, commodities that have a comparative advantage, both in terms of supply, are characterized by superiority in growth in the biophysical, technological, and socio-economic conditions of farmers and demand, which are characterized by strong demand in the market, both domestic and international markets. In simple terms what is meant by superior commodities are commodities that are feasible to be cultivated because they provide benefits to farmers biophysically, socially and economically (Hidayah, 2010). The development of plantation commodities in North Konawe District is certainly expected to be large number of superior commodities and still potential to be superior, coupled with commodities that are not yet superior but are still potentially superior. This certainly requires efforts and encouragement to realize the economic potential of the commodity to be superior in the future. The results of the study (Abidin, 2018) stated that there were several leading commodities in the plantation sector and as a base commodity in North Konawe District including coconut, pepper, cloves and cashew nuts.

The determination of leading commodities in the plantation sector in North Konawe District is the first step towards sustainable agricultural development and rests on the concept of efficiency in order to achieve both comparative and competitive advantages in order to increase regional competitiveness in the face of current and future market competition. Future agricultural development must always be directed to be able to make maximum use of the superiority of regional resources in a sustainable manner (Hidayah, 2010). Based on these conditions, the purpose of this study was to determine the leading commodity in the plantation sector in North Konawe District

\section{MATERIALS AND METHODS}

The study was conducted in North Konawe District in December 2019. The selection of the research object was carried out purposively with the consideration that North Konawe District is one of the regions in Southeast Sulawesi Province which makes the plantation sector as one of the sectors that have potential and plays an important role in improving regional economy. The study was conducted using a literature review method based on secondary data (Wulandari \& Kemala, 2016), namely data obtained from various sources such as the Central Statistics Agency, the Plantation Office, and relevant research results. The analysis of the data used is as follows:

1. Location Quotient Analysis (LQ) is one of the indirect approaches used to determine whether a sector is a base (superior) or a non-base (not superior) sector (Hidayat, 2013). So the LQ technique is relevant if it is used to determine the leading commodities, especially in terms of supply (production). Mathematically, it can be formulated as follows (Hendayana, 2003):

Information:

$$
L Q=\frac{\mathrm{pi} / \mathrm{pt}}{\mathrm{Pi} / \mathrm{Pt}}
$$

\section{$\mathrm{LQ}=$ Location Quotient}

pi $=$ Production value of plantation sector commodities in North Konawe District

pt $=$ Total value of plantation sector commodity production in North Konawe District

$\mathrm{Pi}=$ Production value of plantation sector commodities in Southeast Sulawesi Province

$\mathrm{Pt}=$ Total value of commodity production in the plantation sector in Southeast Sulawesi Province Criteria:

- $\mathrm{LQ}>1$, meaning that plantation sector commodities are basic or superior commodities

- $L Q<1$, meaning that plantation sector commodities are non-base or non-superior commodities.

2. Dynamic Location Quotient (DLQ) analysis was used to state the rate of growth of plantation sector commodities in North Konawe District and in the area of the set. DLQ analysis can also be used to determine the repositioning of leading commodities going forward in certain regions (Hidayat, 2013). Mathematically, it can be formulated as follows:

Information:

$$
\text { DLQij }=\left[\frac{(1+\mathrm{gij}) /(1+\mathrm{gj})}{(1+\mathrm{Gi}) /(1+\mathrm{G})}\right]
$$

DLQij = Dynamic Location Quotient

gij = Average growth of commodity production in the plantation sector in North Konawe District 
gi = Average growth of total commodity production in the plantation sector in North Konawe District

Gi = Average growth rate of commodity production in the plantation sector in Southeast Sulawesi Province

$\mathrm{G}=$ = Average growth rate of total commodity production in the plantation sector in Southeast Sulawesi Province

Criteria:

- DLQ> 1, meaning that the plantation sector commodity in North Konawe District can still be expected to become a base or superior commodity in the future.

- DLQ $<1$, meaning that the plantation sector commodity in North Konawe District cannot be expected to become a base or superior commodity in the future.

3. Based on the combination of the results of the LQ and DLQ analysis, the plantation sector commodity was divided into at least four groups with the following criteria (Ariyani, 2005):

- LQ> 1 and DLQ> 1, meaning that the plantation sector commodities in North Konawe District are superior and still have the potential to be superior.

- $L Q>1$ and $D L Q<1$, meaning that the plantation sector commodities in North Konawe District are superior and have not yet potentials.

- $L Q<1$ and DLQ $>1$, meaning that the plantation sector commodities in North Konawe District are not superior and have the potential to be superior.

- $L Q<1$ and $D L Q<1$, meaning that the plantation sector commodities in North Konawe District are not and have not yet potentials to be superior.

\section{RESULTS AND DISCUSSION}

The plantation sector commodity is one of the main commodities in North Konawe District. Based on data (BPS, 2018), it showed that the plantation sector commodities in North Konawe District include 10 commodities including coconut, oil palm, coffee, pepper, cocoa, cashew, clove, sago, candlenut, and nutmeg. The growth of the plantation sector is expected to be able to provide a significant contribution to agricultural development in North Konawe District, seeing that the plantation sector is one sector with a fairly high land-use area of 143,495 ha or $28.13 \%$ compared to other sectors such as the food crops, forestry sector and animal husbandry (BPS, 2018).

\section{Plantation Sector Commodity Production Growth}

Proportional growth is the difference between regional growth and national growth. The commodity-based or superior plantation sector which has a positive amount shows that the commodity in the District grows faster than the overall commodity growth (Suharni, 2017). The condition of the growth of commodity production in the plantation sector in the North Konawe District was assessed based on the data from 2015 to 2017 (BPS, 2018). An overview of the growth in commodity production in the plantation sector can be seen in Table 1 and Figure 1.

Table 1. Growth in commodity production in the plantation sector in North Konawe District 2015 to 2017.

\begin{tabular}{clrrrr}
\hline \multirow{2}{*}{ No. } & \multicolumn{1}{c}{ Commodity } & \multicolumn{3}{c}{ Production / Years (Ton) } & Growth \\
\cline { 3 - 5 } & & 2015 & 2016 & 2017 & \multicolumn{1}{c}{$(\%)$} \\
\hline 1 & Coconut & 1,589 & 1,041 & 1,041 & -19.06 \\
2 & Palm oil & 594 & 652 & 652 & 4.77 \\
3 & Coffee & 342 & 252 & 271 & -14.16 \\
4 & Pepper & 190 & 134 & 134 & -16.02 \\
5 & Cocoa & 1,418 & 596 & 596 & -35.17 \\
6 & Cashew & 2,510 & 572 & 572 & -52.26 \\
7 & Clove & 311 & 154 & 154 & -29.63 \\
8 & Sago & 1,589 & 361 & 361 & -37.19 \\
9 & Candlenut & 594 & 17 & 17.00 & -47.21 \\
10 & Nutmeg & 342 & 43 & 44.00 & -16.72 \\
\hline & & & & -26.27 \\
\hline
\end{tabular}

Source: Southeast Sulawesi in Figures, 2018.

Based on Table 1 of the amount of production from 2015 to 2017, it shows that almost all plantation sector commodities in the North Konawe District showed negative growth, or in other 
words, the amount of production decreased. This is because in general, the management of farming in the plantation sector in the North Konawe District has not been carried out optimally in the context of increasing the production. This condition is consistent with the results of research conducted by (Abidin, 2015) which explained that the development of the plantation sector in Southeast Sulawesi has not been fully supported by the provision of better facilities and infrastructure. So in general, it illustrated that the management of the plantation sector was still not optimal in the context of increasing production. Increased production and productivity cannot be separated from the factors of production owned by farmers and the effectiveness and efficiency of their farming management (Mardani et al., 2017). From 10 (ten) plantation sector commodities in North Konawe District, there were 9 (nine) commodities that experienced a negative amount of production growth. The negative amount of production growth or the decrease in the highest amount of production was shown by cashew commodities, which amounted to $52.26 \%$, while the negative amount of production growth or the decrease in the lowest amount of production was experienced by coffee commodities by $14.16 \%$. Negative production growth will affect the competitiveness of commodities in the plantation sector in the North Konawe District. In accordance with research conducted by (Abidin, 2015), it explained that in general, the plantation sector in Southeast Sulawesi did not have a comparative advantage yet due to the lack of optimal management of the plantation sector in increasing production. This is also supported by the results of research (Suharni, 2017) which explains that the plantation sub-sector commodity which has a negative proportional growth showing slow growth compared to other commodities, while the growth of the region's share of the negative plantation sub-sector commodity shows weak competitiveness compared to commodities in other regions.

The only commodity in the plantation sector in the North Konawe District that showed positive growth over a period of 3 (three) years was oil palm, which amounted to $4.77 \%$. Positive proportional growth in the plantation sub-sector commodity shows that the commodity has a fast growth compared to other commodities, while positive growth in the share of the region shows that the commodity has competitiveness when compared to other commodities (Suharni, 2017). This is also supported by the results of research (Abidin, 2015) which explains that the economic sector in Southeast Sulawesi was positively influenced by national growth, the contribution of oil palm development which will encourage economic growth and increase capital in the region.

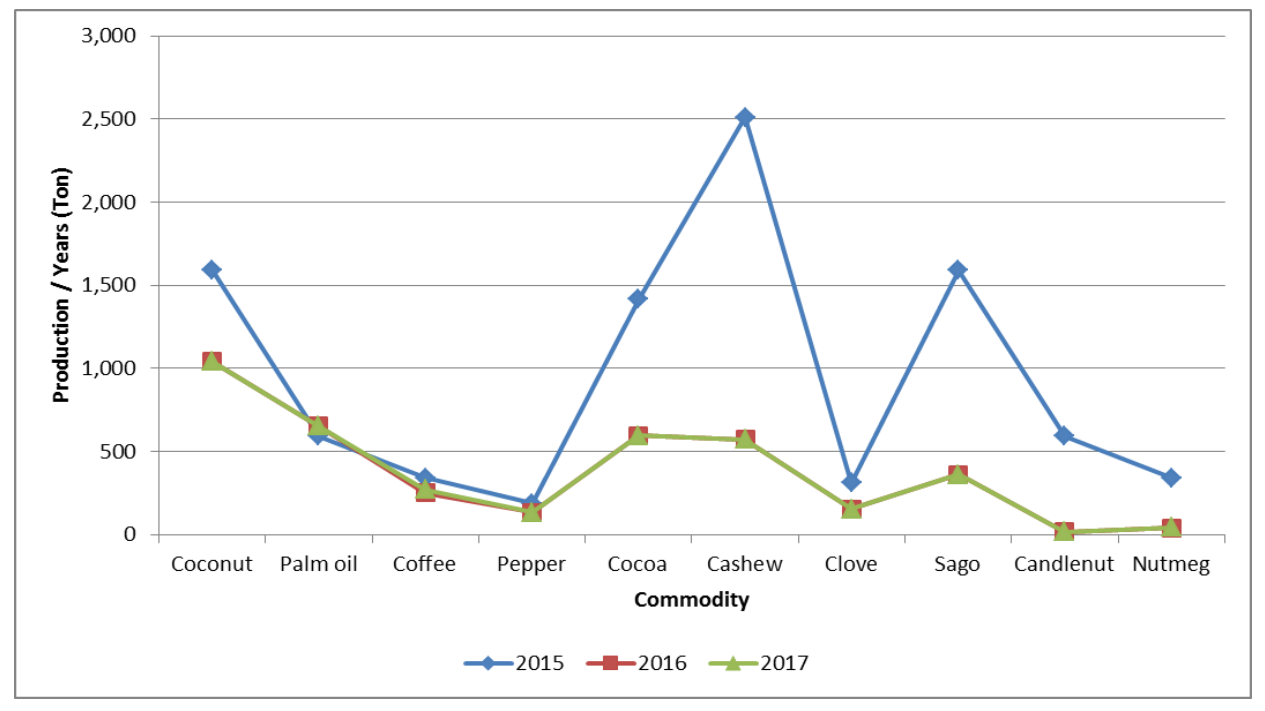

Figure 1. Plantation sector commodity production growth in North Konawe District 2015 to 2017

Figure 1. shows that on average the growth of all plantation commodities in the North Konawe District experienced negative growth or decreased production by $26.27 \%$. The decrease in production was higher compared to the decrease in the average production of Southeast Sulawesi plantation commodities by $13.47 \%$. This also indicates that the decrease in plantation commodity production in North Konawe District was higher than the decrease in plantation commodity production in each district/city in Southeast Sulawesi.

\section{Contribution of Commodity Production in the Plantation Sector}

Contributions have the meaning of donations or parts (Saad, 2006). So that the contribution of production can be interpreted as the amount of contribution or part of the production of plantation 
sector commodities in the North Konawe District to the total production of plantation sector commodities in Southeast Sulawesi Province. An illustration of the contribution of plantation sector commodity production in the North Konawe District to the total production of the plantation sector commodity in Southeast Sulawesi Province can be seen in Table 2 and Figure 2.

Table 2. Contribution of plantation plant commodity production in North Konawe District to the total production of Southeast Sulawesi Province in 2017.

\begin{tabular}{|c|c|c|c|c|}
\hline \multirow{2}{*}{ No } & \multirow{2}{*}{ Commodity } & \multicolumn{2}{|c|}{ Production (Ton) } & \multirow{2}{*}{$\begin{array}{c}\text { Contribution } \\
(\%)\end{array}$} \\
\hline & & North Konawe & Southeast Sulawesi & \\
\hline 1 & Coconut & 1,041 & 46,261 & 2.25 \\
\hline 2 & Palm oil & 652 & 2,627 & 24.82 \\
\hline 3 & Coffee & 271 & 6,968 & 3.89 \\
\hline 4 & Pepper & 134 & 5,134 & 2.61 \\
\hline 5 & Cocoa & 596 & 125,054 & 0.48 \\
\hline 6 & Cashew & 572 & 34,907 & 1.64 \\
\hline 7 & Clove & 154 & 12,835 & 1.20 \\
\hline 8 & Sago & 361 & 2,620 & 13.78 \\
\hline 9 & Candlenut & 17.00 & 907 & 1.87 \\
\hline \multirow[t]{2}{*}{10} & Nutmeg & 44.00 & 422 & 10.43 \\
\hline & & Rata-Rata & & 6.30 \\
\hline
\end{tabular}

Source: Southeast Sulawesi in Figures, 2018.

Table 2 shows that the average contribution of commodity production in the North Konawe District to the total production of the plantation sector in Southeast Sulawesi Province until 2017 was only $6.30 \%$. This was proven by the value of GRDP on the basis of current prices and constant prices according to the field of business which did not place the plantation sector in part one part of the agricultural sector that contributes to the value of the North Konawe District GRDP (BPS, 2019a). In fact, the plantation sector was one sector that should be able to contribute and play an important role in increasing the value of GRDP. According to (Arsyad, 2010), the increase in the value of GDP was caused by increased output sectors, one of which is the plantation sector. The development of the plantation sector will be a support for economic growth, an increase in plantation productivity will be followed by an increase in labor income and in turn will increase the expansion of employment and people's purchasing power (Arsyad, 2010). The low contribution of plantation commodities to the total production of plantation commodities in Southeast Sulawesi will result in the low comparative advantage of plantation commodities in the North Konawe District. This will ultimately have an impact on the low competitiveness of commodities and regional competitiveness. This is because one of the objectives of the management of the plantation sector is to increase productivity and competitiveness (Wulandari \& Kemala, 2016).

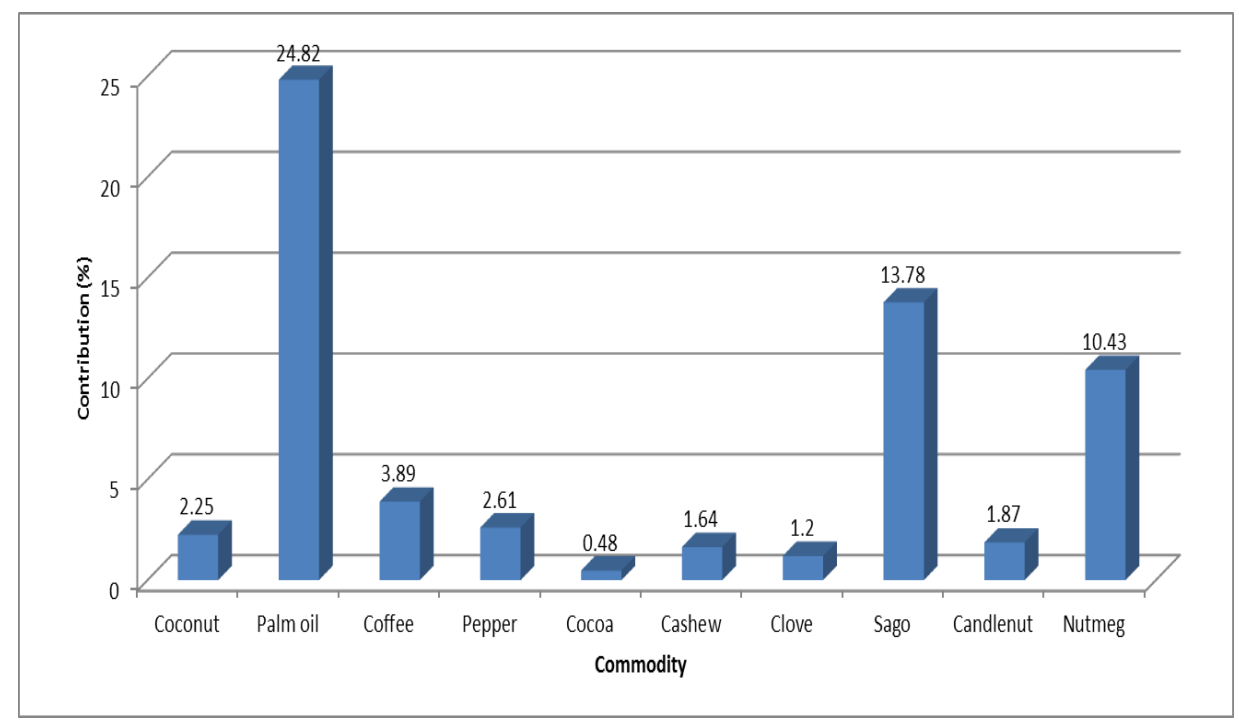

Figure 2. Contribution of commodity production in the plantation sector in North Konawe District to the total production of Southeast Sulawesi Province in 2017 
Figure 2 shows that the plantation commodities of the North Konawe District which had the largest contribution and more than $10 \%$ of the total production of plantation commodities in Southeast Sulawesi Province were oil palm at $24.82 \%$, sago $13.78 \%$, and nutmeg at $10.43 \%$. Meanwhile, the commodities that contributed less than $1 \%$ were cacao by $0.48 \%$. On average, the contribution of all plantation sector commodities in the North Konawe District to the total production of plantation commodities in Southeast Sulawesi was only $6.30 \%$.

\section{Location Quotient Analysis (LQ)}

LQ analysis is a relevant method used to determine leading commodities, especially on the supply (production) side (Hendayana, 2003). The development of plantation sector commodities in North Konawe District certainly is expected to be a large number of superior commodities and still has the potential to excel. An overview of the results of the Location Quotient analysis of plantation sector commodities in North Konawe District can be seen in Table 3.

Table 3. Results of the location quotient analysis of plantation sector commodities in North Konawe District in 2019

\begin{tabular}{|c|c|c|c|}
\hline No & Commodity & Location Quotient & Criteria \\
\hline 1 & Coconut & 1.39 & Superior \\
\hline 2 & Palm oil & 15.36 & Superior \\
\hline 3 & Coffee & 2.41 & Superior \\
\hline 4 & Pepper & 1.62 & Superior \\
\hline 5 & Cocoa & 0.29 & Not Excellent \\
\hline 6 & Cashew & 1.01 & Superior \\
\hline 7 & Clove & 0.74 & Not Excellent \\
\hline 8 & Sago & 8.53 & Superior \\
\hline 9 & Candlenut & 1.16 & Superior \\
\hline 10 & Nutmeg & 6.45 & Superior \\
\hline
\end{tabular}

Source: Secondary data processed, 2019.

Table 3 shows that plantation sector commodities in North Konawe District were mostly or $80 \%$ included in the superior commodity category. Some of these superior commodities such as coconut, oil palm, coffee, pepper, cashew, sago, candlenut, and nutmeg. This can be seen from the LQ value greater than one. This means that some of the plantation sector commodities are commodities that are the basis or source of growth and have an advantage in the North Konawe District. This is also supported by a statement (Zakiah et al., 2015) stating that if the LQ value is greater than one, it indicates a base or superior commodity, meaning that the commodity has a comparative advantage because it is able to meet the needs of its own region and is also able to meet the needs of other regions. The higher the LQ value held by a commodity in an identical area, the higher the potential advantage possessed by that commodity (Pranoto, 2008).

Based on the results of the analysis, it also showed that the plantation sector commodity in North Konawe District with the highest LQ value was palm oil which amounted to $15.36 \%$. The LQ value of oil palm in North Konawe District was in the highest category when compared to the results of studies conducted in several other areas such as the LQ value of oil palm in Muaro Jambi District by $1.58 \%$ (Mukhlis \& Busyra, 2019), the LQ value of oil palm The highest Landak District in 2012 was $1.25 \%$ (Charles et al., 2018) and the LQ value of palm oil in Sumatra Island was $0.90 \%$ (Lyan, 2014). So based on these conditions, oil palm can be used as one of the plantation sector commodities in North Konawe District which is a priority for development. Whereas $20 \%$ of plantation sector commodities in the North Konawe District were included in the category of inferior commodities such as cloves and cocoa. This can be seen from the LQ value smaller than one. This is due to the low amount of production which is generally a result of farming management that is not yet optimal. Increased production and productivity cannot be separated from the factors of production owned by farmers and the management of their farming effectively and efficiently (Mardani et al., 2017).

\section{Dynamic Location Quotient (DLQ) Analysis}

DLQ analysis is used to determine the repositioning of leading commodities going forward in certain regions (Hidayat, 2013). This analysis is important to be used to determine whether in the future the plantation sector commodity can survive as a commodity or not and vice versa whether the commodity which was previously not superior can experience repositioning/potential to become a leading commodity in the future. A description of the determination of plantation sector commodities in the North Konawe District to be a base or superior commodity in the future can be seen in Table 4 . 
Table 4. Results of dynamic location Quotient analysis on plantation sector commodities in North Konawe District in 2019

\begin{tabular}{clcc}
\hline No & \multicolumn{1}{c}{ Commodity } & Dynamic Location Quotient & Criteria \\
\hline 1 & Coconut & -0.42 & Not yet superior \\
2 & Palm oil & -0.48 & Not yet superior \\
3 & Coffee & -0.57 & Not yet superior \\
4 & Pepper & -0.75 & Not yet superior \\
5 & Cocoa & -0.32 & Not yet superior \\
6 & Cashew & -0.29 & Not yet superior \\
7 & Clove & -0.53 & Not yet superior \\
8 & Sago & -0.36 & Not yet superior \\
9 & Candlenut & -0.32 & Not yet superior \\
10 & Nutmeg & -0.41 & Not yet superior \\
\hline
\end{tabular}

Source: Secondary data processed, 2019.

Table 4 shows that in general, the plantation sector commodities in North Konawe District are not yet superior in the future. This can be seen from the value of DLQ which was smaller than one. This means that the proportion of the commodity sector's growth rate to the growth rate of the total value of commodity production in the plantation sector in the North Konawe District was lower when compared to the rate of growth of these commodities to the total production value of Southeast Sulawesi Province. According to (Hidayat, 2013), as long as commodity conditions remain as they are, the future of these commodities will be unable to compete with similar commodities to meet their own territory. In order to be able to achieve production growth rates as expected, it is necessary to identify the constraints of production and the provision of technology packages (Batubara et al., 1996).

\section{Combination of $L Q$ and DLQ}

The repositioning of a commodity in the future can be determined by combining the $L Q$ and DLQ values (Hidayat, 2013). An overview of the results of the combination of LQ and DLQ in the plantation sector commodity in the North Konawe District can be seen in Table 5.

Table 5. Results of a combination of LQ and DLQ at the plantation sector in North Konawe District in 2019

\begin{tabular}{clccl}
\hline No & Commodity & LQ value & DLQ value & \multicolumn{1}{c}{ Criteria } \\
\hline 1 & Coconut & 1.39 & -0.42 & Excellent and Not Potentially Excellent Again \\
2 & Palm oil & 15.36 & -0.48 & Excellent and Not Potentially Excellent Again \\
3 & Coffee & 2.41 & -0.57 & Excellent and Not Potentially Excellent Again \\
4 & Pepper & 1.62 & -0.75 & Excellent and Not Potentially Excellent Again \\
5 & Cocoa & 0.29 & -0.32 & Not Excellent and Not Potentially Excellent Again \\
6 & Cashew & 1.01 & -0.29 & Excellent and Not Potentially Excellent Again \\
7 & Clove & 0.74 & -0.53 & Not Excellent and Not Potentially Excellent Again \\
8 & Sago & 8.53 & -0.36 & Excellent and Not Potentially Excellent Again \\
9 & Candlenut & 1.16 & -0.32 & Excellent and Not Potentially Excellent Again \\
10 & Nutmeg & 6.45 & -0.41 & Excellent and Not Potentially Excellent Again \\
\hline
\end{tabular}

Source: Secondary data processed, 2019.

SLQ and DLQ analysis results showed that for the majority of plantation commodities (80\%) were included in superior commodities and have not yet had the potential to be superior, namely coconut, palm oil, coffee, pepper, cashew, sago, candlenut, and nutmeg. Meanwhile, the remaining 2 commodities $(20 \%)$, namely cocoa and clove commodities, were classified as commodities that were neither superior nor at the same time potential to be superior. The superior commodity which no longer has the potential to be superior due to the high contribution of the commodity to the same commodity at the provincial level in 2018, but its growth during 2014 to 2018 experienced a decrease in production that is much higher than the decrease in commodity production at the level of Sulawesi Province Southeast. Furthermore, commodities that are not yet superior and at the same time have no potential to be superior are due to these commodities having a low contribution to the same commodity at the provincial level in 2018, and the growth from 2014 to 2018 experienced a decrease in production that was much higher than the decrease in commodity production at the Provincial level Southeast Sulawesi. 


\section{CONCLUSION AND RECOMMENDATIONS}

Plantation sector commodities in North Konawe District which are categorized as superior and not yet potential to excel are coconut, oil palm, coffee, pepper, cashew, sago, candlenut, and nutmeg. Meanwhile, the plantation sector commodities in North Konawe District which are classified as not superior and not yet potential to excel are cocoa and clove. It is recommended that the regional government of North Konawe District needs to determine and establish the direction of policies and strategies that encourage increased production and productivity of potential plantation sector commodities as a priority to become a leading commodity capable of increasing the competitiveness of the North Konawe District in the future.

\section{REFERENCES}

Abidin, Z. (2015). Aplikasi Analisis Shift Share pada Transformasi Sektor Pertanian dalam Perekonomian Wilayah di Sulawesi Tenggara. Informatika Pertanian, 24(2), 1-10.

Abidin, Z. (2018). Identifikasi Komoditas Unggulan Wilayah dalam Perspektif Pertanian Berkelanjutan di Sulawesi Tenggara. Jurnal Mega Aktiva, 7(2), 92.

Ariyani, A. H. M. (2005). Peran dan identifikasi komoditas pertanian unggulan di Kabupaten Wonogiri Universitas Gadjah Mada].

Arsyad, L. (2010). Ekonomi Pembangunan Pertanian. BPFE.

Batubara, L. P., Karokaro, S., \& Elieser, S. (1996). Integration of sheep in oil palm plantations in North Sumatra, Indonesia. Proceedings of the first international symposium on the integration of livestock to oil palm production. Malaysian society of animal production (MSAP).

BPS. (2018). Sulawesi Tenggara Dalam Angka. Badan Pusat Statistik.

BPS. (2019a). Kabupaten Konawe Utara Dalam Angka. Badan Pusat Statistik.

BPS. (2019b). Sulawesi Tenggara Dalam Angka. Badan Pusat Statistik.

Charles, F., Suyatno, A., \& Yusra, H. A. (2018). Penentuan Komoditas Unggulan Sektor Pertanian di Kabupaten Landak. Sosial Ekonomi Pertanian Jurnal Agribisnis.

Hendayana, R. (2003). Aplikasi metode Location Quotient (LQ) dalam penentuan komoditas unggulan nasional. Informatika Pertanian, 12(1), 658-675.

Hidayah, I. (2010). Analisis Prioritas Komoditas Unggulan Perkebunan Daerah Kabupaten Buru. AGRIKA, 4(1), 1-8.

Hidayat, R. (2013). Analisis Komoditas Unggulan Sub Sektor Perkebunan di Kabupaten Bengkayang Provinsi Kalimantan Barat. Jurnal Social Ekonomi of Agriculture, 2(1), 54-66.

Iyan, R. (2014). Analisis Komoditas Unggulan Sektor Pertanian di Wilayah Sumatera. Jurnal Sosial Ekonomi Pembangunan, 4(11), 215-235.

Mardani, Nur, T. M., \& Satriawan, H. (2017). Analisis Usahatani Tanaman Pangan Jagung di Kecamatan Juli Kabupaten Bireuen. Jurnal S. Pertanian, 1(3), 203-212.

Mukhlis, \& Busyra. (2019). Penentuan Komoditas Unggulan Sub Sektor Perkebunan di Kabupaten Muaro Jambi. Khazanah Intelektual, 3(1), 341-453.

Pranoto, E. (2008). Potensi Wilayah Komoditas Pertanian Dalam Mendukung Ketahanan Pangan Berbasis Agribisnis Kabupaten Banyumas Universitas Diponegoro]. Semarang.

Rachman, H. (2003). Penentuan Komoditas Unggulan Nasional di Tingkat Provinsi. Makalah Lokakarya 'Sintesis Komoditas Unggulan Nasional'. Bogor.

Saad. (2006). Kontribusi Pengembangan Potensi Pertania Daerah terhadap Kesejahteraan Masyarakat Pedesaan. PT. Eresco.

Suharni. (2017). Analisis Penentuan Komoditas Unggulan Sub Sektor Perkebunan Kabupaten Aceh Barat Universitas Teuku Umar]. Aceh Barat.

Wulandari, S. A., \& Kemala, N. (2016). Kajian Komoditas Unggulan Sub Sektor Perkebunan di Provinsi Jambi. Jurnal Ilmiah Universitas Batanghari Jambi, 16(1), 134-141.

Zakiah, Safrida, \& Santri, L. (2015). Pemetaan Komoditas Unggulan Sub Sektor Perkebunan di Kabupaten Aceh Selatan. Agrisep, 16(1), 35-52. 